Acta vet. scand. $1967,8,279-286$.

From the Department of Medicine, Karolinska Institutet at Serafimerlasarettet and King Gustaf V Research Institute, Stockholm, Sweden.

\title{
ERYTHROCYTE SEDIMENTATION RATE AND PROTEIN-BOUND CARBOHYDRATES IN DOMESTIC ANIMALS
}

By

\author{
L. E. Böttiger ${ }^{\star}$ )
}

The mechanisms of the erythrocyte sedimentation rate (E.S.R.) are still poorly understood. Only few studies have been published dealing with this problem since the nineteen twenties, when the connection between a high E.S.R. and an altered albumin/globulin ratio and a high fibrinogen content first was established by Fåhraeus (1918) and Westergren (1924, 1928).

It has been demonstrated that a connection exists between the E.S.R. and the plasma content of protein-bound carbohydrates; the higher the content, the higher the E.S.R. (Stary et al. 1951). Also a correlation between high E.S.R. and high serum content of sialic acid had been found (Stickl \& Böcker 1959). These authors treated sera from patients with high E.S.R.s with neuraminidase and found that the high E.S.R. was normalized. Although nothing definite can be concluded from such experiments, they nevertheless point to the possibility that protein-bound carbohydrates might play a rôle in the production of a high E.S.R. It is well-known that plasma alfa $a_{1}$ and alfa $a_{2}$ globulins, mainly orosomucoid and haptoglobin, respectively, and fibrinogen increase in a closely parallel way during acute reactions, inflammatory as well as others (infarctions, neoplasms etc.) It has not been possible, however, to distinguish between

*) Supported by a grant from the Swedish Medical Research Council. All samples have been obtained through the courtesy of professor B. Aberg, MD, DVM, at the Royal Veterinary College. 
the rôle played by fibrinogen, which always has been considered to be the most important factor, and the alfa-globulins - if they have any importance at all - for the production of an increased E.S.R. In fact, Ruhenstroth-Bauer (1961) has disputed the importance of the fibrinogen and stated that an increase in fibrinogen or gamma-globulin is only coincidental to a high sedimentation rate and not its cause.

A maximally elevated E.S.R. is found in the healthy horse. The aggregation tendency of erythrocytes of ruminants, on the other hand, is so slight that the E.S.R., in these animals often remains at $0-1 \mathrm{~mm} / \mathrm{hr}$., even during marked inflammatory reactions. The reason for the high E.S.R. in the horse is unknown, as is the reason for the low E.S.R. in ruminants.

I found it of interest to analyse sera from these animals with their widely varying E.S.R. values, to see if the comparison between them could give a clue to direct further studies on the mechanisms of the E.S.R. Proteins and protein-bound carbohydrates have been analysed in whole serum and after zone electrophoretic separation in polyvinyl chloride and on paper.

\section{MATERIAL AND METHODS}

Sera and plasma from healthy animal (horse, cow, sheep and goats) were obtained from the Royal Veterinary College.

Paper electrophoresis was performed in tris-borate-buffer $(\mathrm{pH}$ 8.9). The strips were stained with amidoschwarz $10 \mathrm{~B}$ and scanned in a Beckman Spinco-Analytrol.

PAS-staining was performed according to Köiw \& Grönwall (1952).

Zone electrophoresis was performed in polyvinyl chloride according to the method described by Böttiger \& Carlson (1960 a).

Total serum protein was determined with a biuret method.

Fibrinogen was tetermined by the method of Gram.

Protein-bound carbohydrates were determined by the following methods: hexoses with the anthrone reagent, hexosamines with the Elson-Morgan procedure as described by Blix and sialic acids by the resorcinol-Cu method of Svennerholm (Böttiger \& Carlson $1960 \mathrm{~b}$ ).

E.S.R. was determined with the Westergren method. For horses larger pipettes with a bigger diameter (inner diameter $=9 \mathrm{~mm}$ ) were used.

\section{RESULTS}

The results of protein analyses are given in Table 1. Total plasma protein content is the same in the examined animals as in man. The same holds true for fibrinogen. The mean values in 
Table 1. Erythrocyte sedimentation rate, fibrinogen, total protein and paper electrophoretic fractions, and serum protein-bound carbohydrates in sera from various animals and man. Hematological data at the bottom of the table were obtained from the Department of Clinical Biochemistry, Royal Veterinary College.

\begin{tabular}{|c|c|c|c|c|c|}
\hline & Horse & Cow & Sheep & Goat & Man \\
\hline \multicolumn{6}{|l|}{ Proteins } \\
\hline $\mathrm{g} / 100 \mathrm{ml} \quad \mathrm{n}=$ & 7 & 6 & 6 & 2 & \\
\hline Albumin & 4.0 & 3.1 & 4.4 & 4.0 & 4.8 \\
\hline$\alpha_{1}$-globulin & 0.3 & 0.3 & 0.3 & 0.6 & 0.3 \\
\hline$\alpha_{2}$-globulin & 0.6 & 0.5 & 0.6 & 0.4 & 0.5 \\
\hline$\beta_{1}$-globulin & 0.7 & & & - & \\
\hline $\begin{array}{l}\beta_{2} \text {-globulin } \\
\beta_{3} \text {-globulin }\end{array}$ & 0.5 & 0.7 & 0.3 & $\begin{array}{l}0.2 \\
0.5\end{array}$ & 0.5 \\
\hline$\gamma$-globulin & 1.1 & 2.9 & 0.5 & 2.0 & 1.1 \\
\hline Total protein & 7.1 & 7.5 & 6.0 & 7.6 & 7.2 \\
\hline Fibrinogen & 0.33 & 0.43 & 0.25 & 0.36 & 0.25 \\
\hline \multicolumn{6}{|l|}{$\begin{array}{l}\text { Protein-bound } \\
\text { carbohydrates }\end{array}$} \\
\hline $\mathrm{mg} / 100 \mathrm{ml}$ & & & & & \\
\hline Hexoses & 130 & 128 & 118 & 123 & 111 \\
\hline Hexosamines & 96 & 81 & 76 & 76 & 96 \\
\hline Sialic acids & 63 & 77 & 62 & 67 & 67 \\
\hline Total & 289 & 287 & 256 & 266 & 274 \\
\hline $\begin{array}{l}\text { Carbohydrates \% } \\
\text { of total protein }\end{array}$ & 4.1 & 3.8 & 4.3 & 3.5 & 3.8 \\
\hline $\begin{array}{l}\text { Hemoglobin } \\
\mathrm{g} / 100 \mathrm{ml}\end{array}$ & $12.0--16.4$ & 10.7 & $9-14.5$ & $9-14$ & $12-16$ \\
\hline Hematocrit \% & 36 & 37 & 38 & - & 43 \\
\hline E.S.R. $\mathrm{mm} / \mathrm{hr}$. & 120 & $0-1$ & 1 & 0 & $3-10$ \\
\hline
\end{tabular}

the horse and in the cow are somewhat higher than in man, but on the other hand it is higher in the cow with an E.S.R. $=0-1$ $\mathrm{mm} / \mathrm{hr}$. than in the horse with an E.S.R. above $100 \mathrm{~mm} / \mathrm{hr}$.

Electrophoresis on paper yielded results as given in Table 1. On the whole the curves are similar, but there are a few deviations from the general pattern. In the horse a rapid moving betaglobulin component occurs (Fig. 1). The peak is narrow and situated close to the alfa $a_{2}$-globulin-fraction, which looks as if it had been divided into two parts. Analysis of the carbohydrate content, however, definitely places the peak as a beta-globulin 


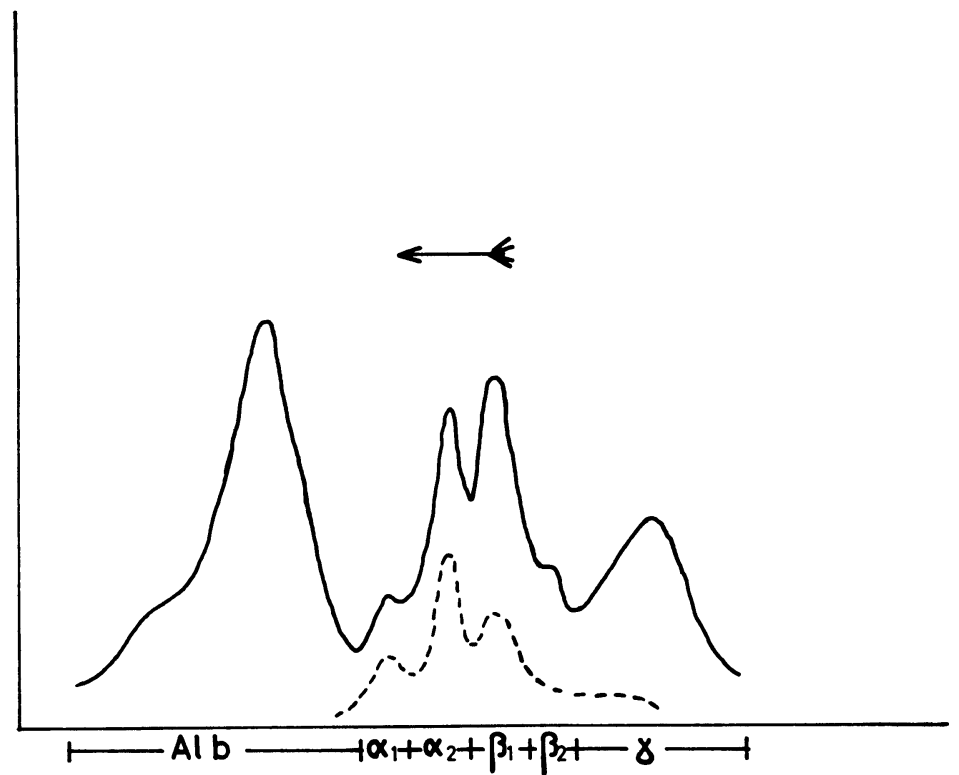

F i g u r e 1. Paper electrophoretic separation of horse serum. Protein (—) and protein-bound carbohydrates, PAS-staining (- - -)

component. This is demonstrated by the PAS-staining, shown in Fig. 1, and further supported by analyses of protein-bound carbohydrates after electrophoretic separation in polyvinyl chloride.

The other distinctive feature is that cattle has a higher gammaglobulin content than other animals. This is in accordance with the findings of Nilsson \& A Aberg (1956) and Nilsson (1958).

The total plasma content of protein-bound carbohydrates (hexoses, hexosamines and sialic acids) did not differ in the animals from that in man (Table 1). The total amount was the same, as was the ratio between the various carbohydrate components. Carbohydrates amount to approximately $4 \%$ of the protein.

In order to study the relative electrophoretic distribution of the carbohydrates, zone electrophoresis was performed in polyvinyl chloride, and protein and protein-bound carbohydrates were analyzed in single fractions. Table 2 gives the relative distributions of protein and protein-bound carbohydrates in the main electrophoretic fractions. Again, the patterns on the whole show good agreement between man and the animals examined.

In the horse serum there is a definite beta-globulin fraction, 
T a b l e 2. Zone electrophoresis - \% distribution of proteins and protein-bound carbohydrates.

\begin{tabular}{|c|c|c|c|c|c|c|}
\hline \multirow[t]{2}{*}{ Proteins } & \multicolumn{3}{|c|}{ Polyvinyl chloride } & \multicolumn{3}{|c|}{ Paper } \\
\hline & Horse & Cow & Man & Horse & Cow & Man \\
\hline Alb & 48 & 41 & 63 & 56 & 42 & 67 \\
\hline$\alpha_{1}$ & 4 & \multirow[t]{2}{*}{14} & 4 & 4 & \multirow[t]{2}{*}{10} & 4 \\
\hline$\alpha_{2}$ & 11 & & 9 & 8 & & 7 \\
\hline$\beta_{1}$ & 9 & \multirow[t]{2}{*}{14} & \multirow[t]{2}{*}{7} & 10 & \multirow[t]{2}{*}{9} & \multirow[t]{2}{*}{7} \\
\hline$\beta_{2}$ & 8 & & & 7 & & \\
\hline \multirow[t]{2}{*}{$\gamma$} & 19 & 30 & 16 & 15 & 39 & 16 \\
\hline & $100 \%$ & $100 \%$ & $100 \%$ & $100 \%$ & $100 \%$ & $100 \%$ \\
\hline \multicolumn{4}{|c|}{ Total protein-bound carbohydrates } & \multicolumn{3}{|c|}{$\begin{array}{l}\text { Total protein-bound carbo- } \\
\text { hydrates } \% \text { of protein }\end{array}$} \\
\hline Alb & 11 & 5 & 4 & 1.2 & 0.5 & 0.3 \\
\hline$\alpha_{1}$ & 12 & \multirow[t]{2}{*}{51} & 20 & 20.4 & \multirow[t]{2}{*}{15.0} & 20.8 \\
\hline$\alpha_{2}$ & 36 & & 33 & 15.7 & & 15.5 \\
\hline$\beta_{1}$ & 14 & \multirow[t]{2}{*}{18} & \multirow[t]{2}{*}{20} & 8.5 & \multirow[t]{2}{*}{5.5} & \multirow[t]{2}{*}{11.9} \\
\hline$\beta_{2}$ & 11 & & & 7.2 & & \\
\hline \multirow[t]{2}{*}{$\gamma$} & 16 & 26 & 23 & 3.9 & 3.3 & 6.1 \\
\hline & $100 \%$ & $100 \%$ & $100 \%$ & & & \\
\hline
\end{tabular}

although not as sharply delined as after separation on paper.

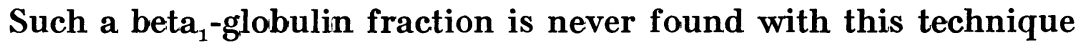
and buffer in human sera. The total carbohydrate content of this beta fraction is much lower than in alfa-globulins (Table 2), a finding that helps to classify the fraction as a beta-globulin.

\section{DISCUSSION}

As stated in the introduction, this study should be regarded as a screening preliminary to direct further research.

The dominant importance of fibrinogen as the main reason 
for a high E.S.R. is to some extent repudiated by the results. The animals with the extreme E.S.R.-values, the horse and the cow, have approximately the same fibrinogen content and the same as man. If anything, the fibrinogen content is higher in the animal with low or actually non-existing erythrocyte sedimentation.

This would be in agreement with the statement by Ruhenstroth-Bauer, when he says that the high fibrinogen content is only coincidental in patients with a high E.S.R.

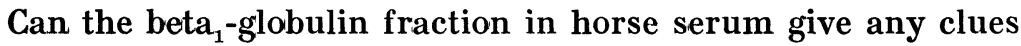
to the mechanisms of the E.S.R.? First, the fraction must be characterized by means of immun-electrophoretic procedures, and further the lipid content should be determined. Theorell (1930) studied the effect of cholesterol and lecithin on the E.S.R. and showed that these substances exerted a retarding effect. However, he found no correlation between the serum lipid level and the E.S.R. He then tested the hypothesis that only cholesterol not bound to fibrinogen or globulins would have effect on the E.S.R. and demonstrated that it was possible to find a negative correlation between the amount of cholesterol that could be extracted with ether and the E.S.R. Later, lipids have been very little discussed in connection with increased sedimentation rate. Recently, however, Larsson (1962) has found a correlation between high sedimentation rate and a low protein-bound iodine in hypothyroidism. He studied protein patterns and found increased beta $a_{2}$-globulins in these patients. He concluded that attention perhaps should be directed more to lipids than had previously been the case.

\section{REFERENCES}

Böttiger, L. E. \& L. A. Carlson: Electrophoretic studies on serum glucoproteins. Clin. chim. Acta 1960 a, 5, 812-817.

Böttiger, L. E. \& L. A. Carlson: Serum glucoprotein concentrations in normal men. Clin. chim. Acta 1960 b, 5, 664-672.

Fåhraeus, R.: Ubber die Ursachen der verminderten Suspensionsstabilität der Blutkörperchen während der Schwangerschaft. Biochem. Z. 1918, 89, 355-364.

Köiw, E.\& A. Grönwall: Staining of protein-bound carbohydrates after electrophoresis of serum on filter paper. Scand. J. clin. Lab. Invest. 1952, 4, $244-246$.

Larsson, $S$. O.: On serum proteins and erythrocyte sedimentation rate in hypothyroidism. Acta med. scand. 1962, 172, 545-554. 
Nilsson, T. \& B. Åberg: Proteins and protein-bound carbohydrates in normal bovine serum. Nord. Vet.-Med. 1956, 8, 975-982.

Nilsson, T.: Blood and milk proteins and protein-bound carbohydrates in bovine chronic mastitis. Acta path. microbiol. scand. 1958, Suppl. 125.

Ruhenstroth-Bauer, G.: Mechanism and significance of erythrocyte sedimentation rate. Brit. med. J. 1961, $i, 1804-1806$.

Stary, Z., H. Bodur \& F. Batiyok: Die Blutsenkungsgeschwindigkeit als Funktion des Glukoproteinsgehalts im Blutplasma. Schweiz. med. Wschr. 1951, 81, 1273-1275.

Stickl, H.\& H. Böcker: Über die Beziehungen zwischen dem Neuraminsäuregehalt des Serums und der Blutkörperschensenkungsgeschwindigkeit. Klin. Wschr. 1959, 37, 635-638.

Theorell, H.: Studien über die Plasmalipoide des Blutes. Biochem. Z. 1930 (Diss.).

Westergren, A.: Die Senkungsreaktion. Ergebn. inn. Med. Kinderheilk. 1924, 26, 577-732.

Westergren, A.: The red cell sedimentation reaction in some acute infectious conditions and in disease of the joints. Int. Clin. 1928, $1,70-77$.

\section{SUMMARY}

Erythrocyte sedimentation rate, total protein and fibrinogen, electrophoretic protein pattern, and total serum protein-bound carbohydrates have been determined in a number of domestic animals and compared to human values. The striking finding is that although the E.S.R. varies widely between various species, the fibrinogen content is of the same order of magnitude in all. The horse, which shows a very high E.S.R., has a well marked beta ${ }_{1}$-globulin fraction as an outstanding feature, a finding that should be further studied.

\section{ZUSAMMENFASSUNG}

Blutsenkungsgeschwindigkeit und proteingebundenen Serumkohlenhydrate.

Blutsenkungsgeschwindigkeit, Gesamteiweiss und Fibrinogen, elektroforetisches Bluteiweissbild sowohl wie proteingebundene Serumkohlenhydrate sind in Sera von Haustiere untersucht worden, und die Resultate sind mit menschlichen Werte verglichen. Obwohl die Blutsenkungsgeschwindigkeit zwischen verschiedene Tierarten sehr verschieden ausfällt, ist doch der Fibrinogengehalt des Serums in den untersuchten Tierarten von derselben Grösse. Das Pferd, das eine sehr hohe Blutsenkungsgeschwindigkeit hat, zeigt im Serum eine scharfe beta - -Globulin Fraktion. Es wird betont, dass weitere Untersuchungen über die Faktoren, die die Blutsenkungsgeschwindigkeit beeinflussen, auch die Lipidfraktionen des Blutserums umfassen sollen. 


\section{SAMMANFATTNING}

Sänkningsreaktion och proteinbundna kolhydrat $i$ serum hos husdjur.

Sänkningsreaktion, serumäggvita och fibrinogen, elektroforetiskt serumäggvitemönster och proteinbundna kolhydrat i serum har bestämts hos husdjur och värdena har jämförts med motsvarande värden hos människa. Trots att SR varierar mycket mellan olika djurslag, är fibrinogeninnehållet i serum hos alla av samma storleksordning. Häs-

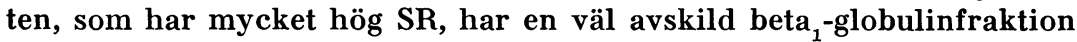
i serum som ett ovanligt fynd. Fortsatta studier över mekanismen för sänkningsreaktionen bör innefatta även studier av serums lipidkomponenter.

(Received May 19, 1967). 